\title{
APLICAÇÃO DA TÉCNICA DE RT-PCR PARA Metapneumovírus aviário (aMPV)
}

\author{
Hiran Castagnino Kunert Filho ${ }^{1}$ \\ Lucas Peretti Hentges ${ }^{2}$ \\ Tiela Trapp Grassotti ${ }^{3}$ \\ Kelly Cristina Tagliari de Brito ${ }^{4}$ \\ Daiane Carvalho ${ }^{5}$ \\ Augusto César da Cunha ${ }^{6}$ \\ Lissandra Souto Cavalli ${ }^{7}$ \\ Luciana Kazue Otutumi $^{8}$ \\ Benito Guimarães de Brito 9
}

\begin{abstract}
KUNERT FILHO, H. C.; HENTGES, L. P.; GRASSOTTI, T. T.; BRITO, K. C. T. de; CARVALHO, D.; CUNHA, A. C. da; CAVALLI, L. S.; OTUTUMI, L. K.; BRITO, B. G. de. Aplicação da técnica de RT-PCR para Metapneumovírus aviário (aMPV). Arq. Ciênc. Vet. Zool. UNIPAR, Umuarama, v. 18, n. 2, p. 75-81, abr.jun. 2015.
\end{abstract}

RESUMO: Os principais hospedeiros do Metapneumovírus aviário (aMPV) são os frangos de corte e perus. O vírus acomete o trato respiratório superior dos perus desencadeando a Rinotraqueíte Viral dos Perus (RVP). O principal objetivo deste trabalho foi padronizar uma técnica de RT-PCR para a detecção do aMPV, por meio do uso do kit AccessQuick RT $^{\mathrm{TM}}$ PCR system $\left(\right.$ Promega $^{\circledR}$ ). Foram utilizados amostras de suabes de traqueia e pulmão de 38 perus comerciais com sintomatologia respiratória e dois suabes oculares de faisão. O RNA viral foi extraído utilizando-se o kit RTP ${ }^{\circledR}$ DNA/RNA Virus Mini Kit (STRATEC Molecular). Em seguida as amostras foram submetidas à RT-PCR One Step, utilizando o kit AccessQuick ${ }^{\mathrm{TM}}$ RT-PCR system $\left(\right.$ Promega $^{\circledR}$ ). Todas as 40 amostras testadas por RT-PCR foram negativas, exceto a amostra vacinal que foi utilizada como controle positivo. O aMPV não causa latência em frangos de corte ou perus, logo a excreção viral é limitada. Dessa forma, a ausência da detecção de genoma viral neste estudo pode ser justificada devido à idade que as amostras foram coletadas em perus, com 140 dias no abatedouro, impossibilitando dessa maneira a amplificação do genoma do aMPV. Porém, esse estudo também mostra que a RT-PCR se mostrou eficaz para detectar o genoma viral do aMPV, podendo dessa forma ser utilizado como uma ferramenta de diagnóstico rápido para investigação e estudo de casos de aMPV em rebanho de perus.

PALAVRAS-CHAVE: Diagnóstico. Metapneumovirus. Perus. RT-PCR.

\section{APPLICATION OF RT-PCR TECHNIQUE FOR Avian metapneumovirus (aMPV)}

\begin{abstract}
The main hosts of Avian metapneumovirus (aMPV) are broilers and turkeys. This virus affects the upper respiratory tract of turkeys, triggering Turkey Rhinotracheitis (TRT). The aim of this study was to optimize a RT-PCR technique in order to detect aMPV using the AccessQuick ${ }^{\mathrm{TM}}$ RT-PCR system (Promega ${ }^{\circledR}$ ) kit. Tracheal and lung swab samples from 38 commercial turkeys with respiratory symptoms and two ocular swabs from pheasants were analyzed. Viral RNA was extracted using RTP ${ }^{\circledR}$ DNA/RNA Virus Mini Kit (Molecular STRATEC) kit. All 40 samples tested were negative in the RT-PCR. The only positive sample was a vaccine strain, used as the positive control. The aMPV does not cause latency in broilers, chickens or turkeys, thus, the viral excretion is limited. However, the absence of viral genome detection in this study may be justified due to the age the samples were collected, since they were collected in turkeys with about 140 days in the slaughterhouse, thus preventing the amplification of the aMPV genome. This study shows that the RT-PCR is effective to detect aMPV viral genome and may be used as a rapid diagnostic tool for research and for the studying of aMPV cases in turkey flocks in Brazil.
\end{abstract}

KEYWORDS: Diagnosis. Metapneumovirus. Turkeys. RT-PCR.

DOI: https://doi.org/10.25110/arqvet.v18i2.2015.5376

${ }^{1}$ Médico Veterinário, Bolsista da FEPAGRO Saúde Animal - Instituto de Pesquisas Veterinárias Desidério Finamor (IPVDF). Laboratório de Saúde das Aves e Inovação Tecnológica, e-mail: hiran_veterinario@hotmail.com. Estrada do Conde 6000, Eldorado do Sul, RS. CEP: 92990-000, Brasil;

${ }^{2}$ Biomédico, Bolsista da FEPAGRO Saúde Animal - Instituto de Pesquisas Veterinárias Desidério Finamor (IPVDF). Laboratório de Saúde das Aves e Inovação Tecnológica, e-mail: lucasph@gmail.com. Estrada do Conde 6000, Eldorado do Sul, RS. CEP: 92990-000, Brasil;

${ }^{3}$ Bióloga, Bolsista da FEPAGRO Saúde Animal - Instituto de Pesquisas Veterinárias Desidério Finamor (IPVDF). Laboratório de Saúde das Aves e Inovação Tecnológica, e-mail: tiela.trapp@gmail.com. Estrada do Conde 6000, Eldorado do Sul, RS. CEP: 92990-000, Brasil;

${ }^{4}$ Bióloga, Pesquisadora da FEPAGRO Saúde Animal - Instituto de Pesquisas Veterinárias Desidério Finamor (IPVDF). Laboratório de Saúde das Aves e Inovação Tecnológica, e-mail: kelly tagliari@hotmail.com. Estrada do Conde 6000, Eldorado do Sul, RS. CEP: 92990-000, Brasil;

${ }^{5}$ Médica Veterinária, Bolsista da FEPAGRO Saúde Animal - Instituto de Pesquisas Veterinárias Desidério Finamor (IPVDF). Laboratório de Saúde das Aves e Inovação Tecnológica, e-mail: daicarvalho vet@hotmail.com. Estrada do Conde 6000, Eldorado do Sul, RS. CEP: 92990-000, Brasil;

${ }^{6}$ Médico Veterinário, Pesquisador da FEPAGRO Saúde Animal - Instituto de Pesquisas Veterinárias Desidério Finamor (IPVDF). Laboratório de Saúde das Aves e Inovação Tecnológica, e-mail: augusto.cunha25@yahoo.com.br. Estrada do Conde 6000, Eldorado do Sul, RS. CEP: 92990-000, Brasil;

${ }^{7}$ Bióloga, Pesquisadorda da FEPAGRO Saúde Animal - Instituto de Pesquisas Veterinárias Desidério Finamor (IPVDF). Laboratório de Saúde das Aves e Inovação Tecnológica, e-mail: liscavalli@gmail.com. Estrada do Conde 6000, Eldorado do Sul, RS. CEP: 92990-000, Brasil;

${ }^{8}$ Médica Veterinária, Professora do curso de Medicina Veterinária e do Mestrado em Ciência Animal da Universidade Paraense - UNIPAR, e-mail: otutumi@ unipar.br. Praça Mascarenhas de Moraes, $n^{\circ}$ 4282. Campus Sede. CEP: 87502-210, Umuarama, Paraná;

${ }^{9}$ Médico Veterinário, Pesquisador da FEPAGRO Saúde Animal - Instituto de Pesquisas Veterinárias Desidério Finamor (IPVDF). Laboratório de Saúde das Aves e Inovação Tecnológica, e-mail: benitobrito@gmail.com. Estrada do Conde 6000, Eldorado do Sul, RS. CEP: 92990-000, Brasil. 


\section{APLICACIÓN DE LA TÉCNICA RT-PCR PARA Metapneumovirus aviario (aMPV)}

RESUMEN: Los principales anfitriones de Metapneumovirus aviario (aMPV) son los pollos de engorde y pavos. El virus afecta el tracto respiratorio superior de los pavos desencadenando la Rinotraqueitis Viral de los pavos (RVP). El principal objetivo de ese estudio fue estandarizar una técnica de RT-PCR para la detección del aMPV, a través del uso del kit AccessQuick ${ }^{\mathrm{TM}}$-PCRsystem (Promega ${ }^{\circledR}$ ). Se utilizaron muestras de hisopos traqueales y pulmonares de 38 pavos comerciales con síntomas respiratorios y dos hisopos oculares de faisán. El RNA viral se extrajo utilizando el kit DNA RTP ${ }^{\circledR}$ DNA/RNA Virus Mini Kit (STRATEC Molecular). A continuación, las muestras se sometieron a la RT-PCR OneStep utilizando el kit Access Quick ${ }^{\mathrm{TM}}$ RT-PCR (Promega ${ }^{\circledR}$ ). Todas las 40 muestras analizadas por RT-PCR fueron negativas, excepto la muestra de vacuna que se utilizó como control positivo. El aMPV no causa latencia en pollos de engorde o pavos, por lo que la excreción viral es limitada. Así, la ausencia de la detección de genoma viral en este estudio puede ser justificada debido a la edad que se recogieron las muestras en los pavos, con 140 días en el matadero, imposibilitando de este modo la amplificación del genoma del aMPV. Sin embargo, ese estudio también muestra que la RT-PCR se ha demostrado eficaz para detectar el genoma viral del aMPV, pudiendo así ser utilizado como una herramienta de diagnóstico rápido para investigación y estudio de casos de aMPV en bandada de pavos.

PALABRAS CLAVE: Diagnóstico. Metapneumovirus. Pavos. RT-PCR.

\section{Introdução}

Um dos principais agentes respiratórios que está propiciando significativas perdas econômicas para avicultura industrial é o Metapneumovírus aviário (aMPV) (GAMA et al., 2006). O aMPV tem como hospedeiro natural as galinhas e os perus. Nos perus afeta o trato respiratório superior desencadeando a Rinotraqueíte Viral dos Perus (RVP) (CECCHINATO et al., 2014). Entretanto, já foi isolado de aves silvestres como galinha d'angola (PICAULT et al., 1987), avestruzes (CADMAN et al., 1994), patos (TOQUIN et al., 1999), pardais, gaivotas, gansos, andorinhas (SHIN et al., 2002) e faisões (LEE et al., 2007).

A infecção pelo aMPV causa uma doença respiratória aguda caracterizada por descarga nasal e ocular, conjuntivite espumosa, congestão facial, inchaço dos seios infraorbitários, edema submandibular, além de queda de postura e ovos de baixa qualidade em perus (WEI et al., 2014). Em frangos de corte e/ou aves de postura o aMPV está associado a problemas respiratórios, à Síndrome da Cabeça Inchada (SCI), sinais nervosos (torcicolo, opistótono e falta de coordenação) e queda na produção e qualidade dos ovos (ARNS et al., 2000). Quadro respiratório geralmente é secundário a presença de Escherichia coli (ZANDE et al., 2001).

O aMPV foi descrito pela primeira vez na África do Sul em 1978 (BUYS; DU PREEZ, 1980). Países como Japão e os Estados Unidos também já descreveram casos com o aMPV (DROUIN et al., 1985; WYETH et al., 1987; COOK et al., 1988; HAFEZ, 1993; TANAKA et al., 1995; COOK et al., 1999). Arns et al. (1997) identificaram a presença de anticorpos contra aMPV nas principais regiões avícolas do Brasil. No Brasil o aMPV foi isolado inicialmente por Arns e Hafez (1995).

$\mathrm{O}$ vírus pertence à ordem Mononegavirales, à família Paramyxoviridae, subfamília Pneumovirinae, gênero Metapneumovírus (GOUGH; JONES, 2008). As partículas virais oscilam entre 70-600 nM de diâmetro e possuem um envelope lipídico com presença de espículas (diferentemente de membros da família Paramyxoviridae o aMPV não apresenta nenhuma atividade de neuraminidase ou de hemaglutinina) (O’LOAN et al., 1992). Seu genoma se caracteriza por ser um RNA de fita simples, não segmentado, de sentido negativo com aproximadamente $13 \mathrm{~kb}$, no sentido 3 '-leader-N-P-M-F-M2-SH-G-L-trailer-5' (ABDEL-AZEEM et al.,
2014) que codifica oito transcritos, denominados: Nucleoproteína $(\mathrm{N})$, fosfoproteína $(\mathrm{P})$, proteína Matrix $(\mathrm{M})$, proteína de Fusão (F), segunda Matrix (M2), pequena proteína hidrofóbica $(\mathrm{SH})$, proteína de ligação $(\mathrm{G})$ e a proteína RNA polimerase dependente do RNA viral (L) (NJENGA et al., 2003).

Atualmente já foram identificados quatro subtipos de aMPV (A, B, C e D). Os subtipos são classificados com base na sequência do seu genoma que codifica a glicoproteína G (JUHASZ; EASTON, 1994; TOQUIN et al., 2000; SHIN et al., 2002). Na Europa, os subtipos predominantes são A e B (JUHASZ \& EASTON, 1994) e esporadicamente o subtipo D (BÃYON-AUBOYER et al., 2000). Já o subtipo C é encontrado nos EUA (LIMAN; RAUTENSCHLEIN, 2007). Os subtipos A e B já foram descritos no Brasil para galinhas, aves silvestres e perus (D'ARCE et al., 2005; CHÁCON et al., 2007; CHACÓN et al., 2011; FELIPPE et al., 2011). Villareal et al. (2009) e Chácon et al. (2011) relatam a predominância do subtipo $\mathrm{B}$ em frangos de corte e perus comerciais.

Os testes sorológicos para detecção de anticorpos mais frequentes empregados para o aMPV são: ensaio imunoenzimático (ELISA) (GRANT et al., 1987) e teste de soroneutralização (COOK et al., 1988). O teste de ELISA apresenta sensibilidade de $98,7 \%$ e especificidade de $99,5 \%$ (HECKERT et al., 1994). Alkahalaf et al. (2002) em um estudo prévio demonstraram que estes dois testes são sensíveis e específicos para diagnosticar o aMPV em perus. Para detecção viral, dentre as técnicas mais utilizadas destacam-se a imunoperoxidase (IPX) (O'LOAN; ALLAN, 1990; CATELLI et al., 1998) e a imunofluorescência (JONES et al., 1988). Mais recentemente a técnica da transcriptase reversa da reação em cadeia da polimerase (RT-PCR) e RT nested-PCR tem sido extensivamente utilizada para a detecção do genoma do aMPV. Ambas as técnicas são eficientes e específicas para a detecção dos subgrupos A, B, C e D do aMPV (JUHASZ; EASTON, 1994; BÃYON-AUBOYER et al., 1999; BÃYON-AUBOYER et al., 2000; TOQUIN et al., 2003). Atualmente a técnica de RT-PCR em tempo real também tem sido utilizada para detecção dos subtipos específicos de aMPV (GUIONIE et al., 2007).

Devido à alta disseminação e aos prejuízos para a indústria avícola, a implantação de um método de diagnóstico rápido é necessária para o controle eficiente da doença e disseminação do aMPV. O objetivo deste estudo foi padroni- 
zar uma técnica de RT-PCR para a detecção do aMPV, através do uso do kit Access Quick ${ }^{\mathrm{TM}}$ RT-PCR system (Promega ${ }^{\circledR}$ ).

\section{Material e Métodos}

Para extração do ácido nucleico do aMPV foram coletados suabes de traqueia e pulmão de 38 perus comerciais provenientes de abatedouro do estado do Paraná, Brasil, com idade de 140 dias apresentando sintomatologia respiratória. Também foram utilizados dois suabes oculares de dois faisões adultos com idade aproximada de dois anos, proveniente do estado do Rio Grande do Sul, Brasil (Quadro 1). Como controle positivo foi utilizada uma amostra vacinal atenuada do aMPV subtipo A.

Quadro 1: Amostras utilizadas no experimento

\begin{tabular}{|c|c|c|c|}
\hline Espécie & Amostra & Local & 19 \\
\hline Peru & Traqueia & Paraná & 19 \\
\hline Peru & Pulmão & Paraná & 2 \\
\hline Faisão & Suabe ocular & Rio Grande do Sul & 1 \\
\hline- & Vacina viva atenuada & - & 41 \\
\hline
\end{tabular}

O ácido nucleico viral, tanto das amostras quanto do controle positivo, foi extraído por meio da utilização do kit RTP ${ }^{\circledR}$ DNA/RNA Virus Mini Kit (STRATEC Molecular $\mathrm{GmbH}$, Berlim) de acordo com instruções do fabricante. As amostras foram armazenadas em solução específica RNALater $^{\circledR}$ (Life Technologies) até seu uso para evitar a degradação do RNA amostral.

Após a extração do RNA, o mesmo foi diretamente submetido à RT-PCR One Step, utilizando o kit Access Qui$c k^{\mathrm{TM}}$ RT-PCR system (Promega ${ }^{\circledR}$ ), conforme instruções do fabricante, utilizando os oligonucleotídeos Nf 5' - GCAAAACACACCGACTATGAG - 3' e Nr 5' - TAGACCTCAGATACTTGCCTC - 3' (FERREIRA et al., 2009) específi- cos para o gene N do aMPV (Quadro 2). As condições do termociclador utilizadas para esta reação foram: transcrição reversa a $45^{\circ} \mathrm{C}$ por 45 minutos e posteriores 35 ciclos de desnaturação a $94{ }^{\circ} \mathrm{C}$ por 35 segundos, anelamento a $56{ }^{\circ} \mathrm{C}$ por 35 segundos, extensão a $72{ }^{\circ} \mathrm{C}$ por 35 segundos e seguido de uma extensão final de $72{ }^{\circ} \mathrm{C}$ por 5 minutos. Os tamanhos de fragmento esperados eram de 698 pares de base.

Para visualização dos produtos amplificados na PCR foi aplicado $5 \mu \mathrm{L}$ de cada amostra em um gel de agarose a $1.0 \%$ diluído em tris-acetato-EDTA (TAE) corado com brometo de etídio. As amostras foram aplicadas no gel e submetidas a uma tensão de 90 volts por 60 minutos para a realização da migração dos amplicons.

Quadro 2: Primers utilizados na reação de PCR

\begin{tabular}{|c|l|c|c|c|}
\hline Nome & \multicolumn{1}{|c|}{ Sequência } & Gene & Posição & Referência \\
\cline { 1 - 4 } $\mathrm{Nf}$ & 5' - GCAAAACACACCGACTATGAG - 3' & $\mathrm{N}$ & $215-235$ & \multirow{2}{*}{ Ferreira et al. (2009) } \\
\hline $\mathrm{Nr}$ & 5' - TAGACCTCAGATACTTGCCTC - 3' & $\mathrm{N}$ & $892-912$ & \\
\hline
\end{tabular}

Todas as amostras foram testadas para Pasteurella multocida por isolamento microbiológico convencional (FURIAN et al., 2013) e submetidas a PCR para Mycoplasma gallisepticum (NASCIMENTO et al., 1991) e Mycoplasma synoviae (LAUERMAN et al., 1994).

\section{Resultados e Discussão}

Todas as 40 amostras testadas por RT-PCR convencional foram negativas para o aMPV, ocorrendo amplificação apenas da amostra vacinal (Figura 1). Todas as espécies utilizadas neste ensaio não foram vacinadas para aMPV para assegurar que os produtos amplificados não seriam oriundos de amostras vacinais. No isolamento para $P$. multocida não houve crescimento característico para este agente no ágar sangue. De mesmo modo, na PCR para M. gallisepticum e M. synoviae não houve amplificação.
Figura 1: Gel de agarose a 1\% corado com Brometo de Etídio. $\mathbf{C}+$ Controle positivo, amostra vacinal atenuada. Poços de 1 a 5: amostras de perus com sintomatologia clínica do aMPV. M: marcador de peso molecular $1 \mathrm{~Kb}$.

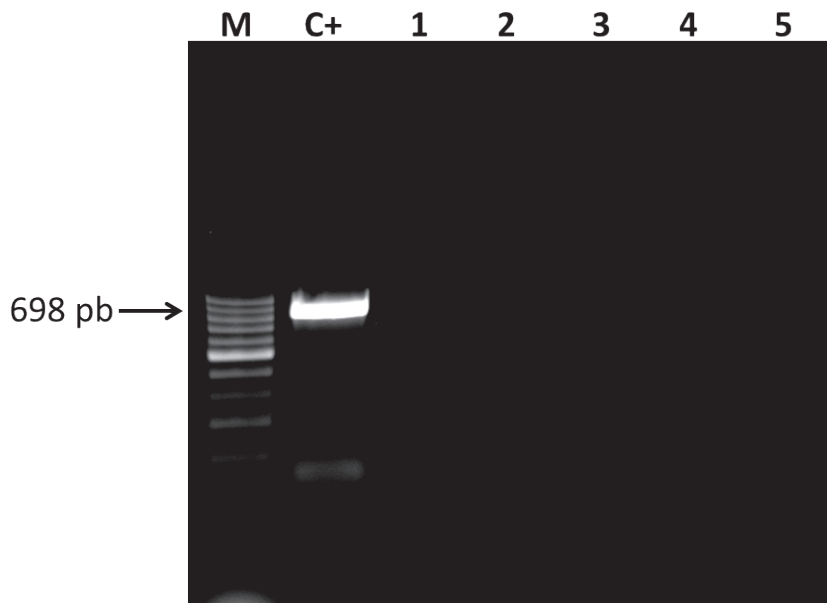

Boaro et al. (2004) e Toro et al. (1998) não detectaram anticorpos contra o aMPV em soros de frangos de corte no Rio Grande do Sul e no Chile, respectivamente. Porém, quando utilizado o teste de ELISA, nas amostras chilenas, foi 
reportado $11,1 \%$ de soros suspeitos. De acordo com Boaro et al. (2004), se as amostras fossem coletadas em matrizes de corte ou de postura com sintomatologia clínica de doença respiratória os resultados obtidos seriam diferentes.

O primeiro relato de infecção aguda no trato respiratório superior de perus foi na África do Sul em 1978 por Buys e Dupreez (1980). Desde então, infecções pelo aMPV em galinhas ou perus, já foram descritas em outros países: França (ANDRAL et al., 1985), no Reino Unido (O'BRIEN, 1985; WILDING et al., 1986) e em outros países europeus (COOK et al., 1993, NAYLOR; JONES, 1993). O aMPV já foi relatado em Israel (WEISMAN et al., 1988), Canadá (ZELLEN, 1988), México (DECANINI et al., 1991), Brasil (ARNS; HAFEZ 1992) e mais recentemente nos EUA (SENNE et al., 1997; COOK et al., 1999) e Coréia (LEE et al., 2007). Já na Austrália e no Canadá, Heckert e Myers (1993), relataram a ausência de anticorpos para aMPV. Recentemente Bennett et al. (2004) detectaram o RNA do aMPV em aves selvagens canadenses. Estes dados sugerem uma distribuição cosmopolita do vírus, pelo menos nos países de alta produção avícola industrial, excluindo-se a Austrália (COOK, 2000).

A doença clínica pelo aMPV geralmente é observada entre os dias dois a 10 pós-infecção $(\mathrm{PI})$, com a maior incidência e severidade dos sinais clínicos entre os dias cinco e sete PI (McDOUGALL; COOK, 1986; COOK et al., 1993; NAYLOR; JONES, 1994; VAN DE ZANDE et al., 1999; JIRJIS et al., 2002; MARIEN et al., 2005). Em frangos de corte o genoma viral já foi detectado até 28 dias PI em suabes clocais (HESS et al., 2004). Banet-Noach et al. (2009) e Cecchinato et al. (2010) evidenciaram a presença do aMPV em plantéis de frango de corte vacinado e atribuem essa infecção por um subtipo ainda não incluído em vacinas, ou por uma possível reversão da virulência (CATELLI et al., 2006) ou devido a alta variabilidade genética entre as amostras circulantes a campo (BANET-NOACH et al., 2009; CATELLI et al., 2010). Segundo Torres et al. (2014), uma vacina que contenha mais distinção genética poderá permitir uma maior proteção contra o aMPV devido ao maior número de subtipos do vírus presente na vacina.

De acordo com este estudo pode concluir-se que a duração da excreção viral é limitada e que não corre estado latente do vírus tanto em frangos de corte quanto em perus. A ausência da detecção de genoma viral neste estudo pode ser justificada devido à idade que as amostras foram coletadas em perus, com 140 dias no abatedouro, impossibilitando dessa maneira a amplificação do genoma do aMPV. Entretanto, esse estudo também mostra que a RT-PCR foi eficiente para detectar o genoma viral do aMPV, extraído de uma amostra vacinal atenuada, podendo ser utilizado como uma ferramenta de diagnóstico rápido para investigação e estudo de casos de aMPV em criações de perus.

\section{Agradecimentos}

Ao Conselho Nacional de Desenvolvimento Científico e Tecnológico (CNPq), Financiadora de Estudos e Projetos (FINEP) e a Fundação de Amparo à Pesquisa do Estado do Rio Grande do Sul (FAPERGS) pela concessão de bolsas e auxílio financeiro.

\section{Referências}

ABDEL-AZEEM, S. A. A. et al. First evidence of avian metapneumovirus subtype A infection in turkeys in Egypt. Tropical Animal and Health Production, v. 46, n. 6, p. 1093-1097, 2014.

ALKAHALAF, A. N.; HALVORSON, D. A.; SAIF, Y. M. Comparison of enzyme linked immunosorbent assays and virus neutralization test for detection of antibodies to avian pneumovirus. Avian Disease, v. 46, n. 3, p. 700-703, 2002.

ANDRAL, B. et al. Respiratory disease (rhinotracheitis) in turkeys in Brittany, France, 1981-1982. II. Laboratory findings. Avian Disease, v. 29, n. 1, p. 35-42, 1985.

ARNS, C.; HAFEZ, H. M. Swollen head syndrome in poultry flocks in Brazil. In: WESTERN POULTRY DISEASE CONFERENCE, 41., 1992, Sacramento. Procedings... Sacramento, 1992. p. 81-84.

ARNS, C. W.; HAFEZ, H. M. Isolation and identification of avian pneumovirus from broiler breeder flocks in Brazil. In: WESTERN POULTRY DISEASES CONFERENCE, 44., 1995, Sacramento. Procedings... Sacramento, 1995. p. 124-125.

ARNS, C. W. et al. Situation of avian pneumovirus in Brazil. Virus Reviews and Research, v. 2, n. 1, p. 101-102, 1997.

ARNS, C. W.; COSWIG, L. T.; MONTEIRO, M. C. G. B. Pneumovirose aviária. In: ___ Doença das aves. Campinas: Facta, 2000. p. 359-363.

BANET-NOACH, C. et al. Longitudinal survey of avian metapneumoviruses in poultry in Israel: infiltration of field strains into vaccinated flocks. Avian Disease, v. 53, n. 2, p. 184-189, 2009.

BÃYON-AUBOYER, M. H. et al. Nucleotide sequences of the $\mathrm{F}, \mathrm{L}$ and $\mathrm{G}$ protein genes of two non-A/non-B avian pneumovirus (APV) reveal a novel APV subgroup. Journal of General Virology, v. 81, n. 11, p. 2723-273, 2000.

BÃYON-AUBOYER, M. H. et al. Comparison of F-, G- and N-based RT-PCR protocols with conventional virological procedures for the detection and typing of turkey rhinotracheitis virus. Archives of Virology, v. 144, n. 6, p. 1091-1109, 1999.

BENNETT, R. S. et al. Evidence of avian pneumovirus spread beyond Minnesota among wild and domestic birds in central North America. Avian Disease, v. 48, n. 4, p. 902908, 2004.

BOARO, L. et al. Ausência de anticorpos contra o vírus da Síndrome da Cabeça Inchada em frangos de corte no Planalto Médio do Rio Grande do Sul, Brasil. Ciência Rural, v. 34, n. 1, p. 285-287, 2004. 
BUYS, S. B.; DU PREEZ, J. H. A preliminary report on the isolation of a virus causing sinusitis in turkeys in South Africa and attempts to attenuate the virus. Turkeys, v. 28, p. 36-40, 1980.

CADMAN, H. F. et al. A serosurvey using enzyme-linked immunosorbent assay for antibodies against poultry pathogens in ostriches (Struthio camelus) from Zimbabwe. Avian Disease, v. 38, n. 3, p. 621-625, 1994.

CATELLI, E. et al. The use of virus isolation, histopathology and immunoperoxidase techniques to study the dissemination of a chicken isolate of Avian Pneumovirus in chickens. Avian Pathology, v. 27, n. 6, p. 632-640, 1998.

CATELLI, E. et al. Demonstration of loss of attenuation and extended field persistence of a live avian metapneumovirus vaccine. Vaccine, v. 24, n. 42-43, p. 6476-6482, 2006.

CATELLI, E. et al. Field avian metapneumovirus evolution avoiding vaccine induced immunity. Vaccine, v. 28, n. 4, p. 916-921, 2010

CECCHINATO, M. et al. Avian metapneumovirus (AMPV) attachment protein involvement inprobable virus evolution concurrent with mass live vaccine introduction. Veterinary Microbiology, v. 146, n. 1-2, p. 24-34, 2010.

CECCHINATO, M. et al. Reversion to virulence of a subtype B avian metapneumovirusvaccine: Is it time for regulators to require availability of vaccine progenitors? Vaccine, v. 32, n. 36, p. 4660-4664, 2014

CHACÓN, J. L. et al. Detection by reverse transcriptase polymerase chain reaction and molecular characterization of subtype B avian metapneumovirus isolatedin Brazil. Avian Pathology, v. 36, n. 5, p. 383-387, 2007.

CHACÓN, J. L. et al. Avian metapneumovirus subtypes circulating in Brazilian vaccinated and nonvaccinated chicken and turkey farms. Avian Disease, v. 55, n. 1, p. 82-89, 2011

COOK, J. K. A. et al. Demonstration of antibodies to turkey rhinotracheitis virus in serum from commercially reared flocks of chickens. Avian Pathology, v. 17, n. 2, p. 403410,1988

COOK, J. K. et al. Antigenic differentiation of strains of Turkey Rhinotracheitis virus using monoclonal antibodies. Avian Pathology, v. 22, n. 2, p. 257-273, 1993.

COOK, J. K.A. et al. Preliminary antigenic characterization of an avian pneumovirus isolated from commercial turkeys in Colorado, USA. Avian Pathology, v. 28, n. 6, p. $607-$ 617,1999

COOK, J. K. Avian rhinotracheitis. Revue Scientifique et Technique, v. 19, n. 2, p. 602-613, 2000.

D'ARCE, C. F. et al. Subtyping of new Brazilian avian metapneumovirus isolates from chickens and turkeys by reverse transcriptase-nested-polymerase chain reaction. Avian Pathology, v. 34, n. 2, p. 133-136, 2005.

DECANINI, E.; MIRANDA, E.; LE GROS, F. Swollen head syndrome in heavy breeders in Mexico. In: WESTERN POULTRY DISEASE CONFERENCE, 40., 1991. Acapulco. Proocedings... Acapulco, 1991. p. 158161.

DROUIN, P.; TOUX, J. Y.; PICAULT, J. P. Le syndrome infectieux de la grosse tête chez l'espèce poule.

L'Aviculteur, v. 460, p. 93-96, 1985.

EASTON, A. J.; DOMACHOWSKE, J. B.; ROSENBERG, H. F. Animal pneumoviruses: molecular genetics and pathogenesis. Clinical Microbiology Reviews, v. 17, n. 2, p. $390-412,2004$

FELIPPE, P. A. N. et al. Detection of and phylogenetic studies with avian metapneumovirus recovered from feral pigeons and wilds birds in Brazil. Avian Pathology, v. 40, n. 5, p. 37-44. 2011.

FERREIRA, H. L. et al. Comparative evaluation of conventional RT-PCR and real-time RT-PCR (RRT-PCR) for detection of avian metapneumovirus subtype A. Ciência Rural, v. 39, n. 5, p. 1445-1451, 2009.

FURIAN, T. Q. et al. Detection of virulence-associated genes of Pasteurella multocida isolated from cases of fowl cholera by multiplex-PCR. Pesquisa Veterinária Brasileira, v. 33, n. 2, p. 177-182, 2013.

GAMA, N. M. S. Q. et al. Doenças respiratórias. Avicultura Industrial, v. 6, n. 1140, p. 24-28, 2006.

GUIONIE, O. et al. Laboratory evaluation of a quantitative real-time reverse transcription PCR assay for the detection and identification of the four subgroups of avian metapneumovirus. Journal of Virological Methods, v. 139, n. 2 , p. $150-158,2007$.

GOUGH, R. E. et al. Experimental infection of turkeys, chickens, ducks, geese, guinea fowl, pheasants and pigeons with turkey rhinotracheitis virus. Veterinary Record, v. 123, n. 2, p. 58-59, 1988.

GOUGH, R. E.; JONES, R. C. Avian metapneumoviruses. In: SAIF, Y. M. et al. Diseases of poultry. 12. ed. Ames: Iowa State Press, 2008. p.100-110.

GRANT, M.; BAXTER-JONES, C.; WILDING, G. P. An enzymelinked immunosorbent assay for the serodiagnosis of turkey rhinotracheitis infection. Veterinay Record, v. 120, n. 12 , p. 279-280, 1987.

HAFEZ, H. M. The role of pneumovirus in the swollen head syndrome of chickens: review. Archiv für Geflügelkunde, v. 57, p. 181-185, 1993. 
HECKERT, R. et al. Development and evaluation of an enzyme linked immunosorbent assay for the detection of antibodies to avian pneumovirus. Avian Disease, v. 38, n. 4, p. 694-700, 1994.

HESS, M. et al. Avian metapneumovirus excretion in vaccinated and non-vaccinated specified pathogen free laying chickens. Avian Pathology, v. 33, n. 1, p. 35-40, 2004.

JIRJIS, F. F. et al. Pathogenesis of avian pneumovirus infection in turkeys. Veterinary Pathology, v. 39, n. 3, p. 300-310, 2002.

JONES, R. C. et al. Experimental infection of laying turkeys with Rhinotracheitis virus: distribution of virus in the tissues and serological response. Avian Pathology, v. 17, n. 4, p. 841-850, 1988.

JUHASZ, K.; EASTON, A. J. Extensive sequence variation in the attachment $(\mathrm{G})$ protein gene of avian pneumovirus: evidence for two distinct subgroups. Journal of General Virology, v. 75, n. 11, p. 2873-2880, 1994.

LAUERMAN, L. H. et al. Development and application of a polymerase chain reaction assay for Mycoplasma synoviae. Avian Disease, v. 37, n. 3, p. 829-834, 1993.

LEE, E. et al. Genetic characterizationof avian metapneumovirus subtype $\mathrm{C}$ isolated from pheasants in a live birdmarket. Virus Research, v. 128, n. 1-2, p. 18-25, 2007.

LIMAN, M.; RAUTENSCHLEIN, S. Induction of local and systemic immune reactions following infection of turkeys with avian Metapneumovirus (aMPV) subtypes A and B. Veterinary Immunology and Immunopathology, v. 115, n. 3-4, p. 273-285, 2007.

MARIEN, M. et al. Synergy between avian pneumovirus and Ornithobacterium rhinotracheale in turkeys. Avian Pathology, v. 34, n. 3, p. 204-211, 2005.

McDOUGALL, J. S.; COOK, J. K. Turkey rhinotracheitis: preliminary investigations. Veterinary Record, v. 118, n. 8, p. 206-207, 1986.

NASCIMENTO, E. R. et al. Polymerase chain reaction for detection of Mycoplasma gallisepticum. Avian Disease, v. 35, n. 1, p. 62-69, 1991.

NAYLOR, C.; JONES, R. C. Turkey Rhinotracheitis: a review. Veterinary Bulletin, v. 63, p. 339-349, 1993.

NJENGA, M. K.; LWAMBA, H. M.; SEAL, B. S. Metapneumoviruses in birds and humans. Virus Research, v. 91, n. 2, p. 163-169, 2003.

O'BRIEN, J. D. Swollen head syndrome in broiler breeders. Veterinary Record, v. 117, n. 23, p. 619-620, 1985.
O’LOAN, C. J.; CURRAN, W. L.; MCNULTY, M. S. Immuno-gold labelling of turkey rhinotracheitis virus. Zentralbl Veterinärmed B, v. 39, n. 6, p. 459-466, 1992.

O'LOAN, C. J.; ALLAN, G. M. The detection of Turkey rhinotracheitis virus antigen in formalin fixed, paraffin embedded tissue, using a streptavidin-biotinimmunoperoxidase method. Avian Pathology, v. 19, n. 2, p. 401-407, 1990.

PICAULT, J. P. et al. Isolation of a TRTV-like virus from chickens with swollen head syndrome. Veterinary Record, v. 121, n. 6, p. $135,1987$.

SENNE, D. et al. Avian pneumovirus update. In: ANNUAL CONGRESS OF THE AMERICAN VETERINARY MEDICAL ASSOCIATION, 134., 1997, Reno.

Procedings... Reno, 1997. p. 190-191.

SHIN, H. J. et al. Molecular epidemiology of subgroup $\mathrm{C}$ avian pneumoviruses isolated in the United States and comparison with subgroup A and B viruses. Journal of Clinical Microbiology, v. 40, n. 5, p. 1687-1693, 2002.

TANAKA, M. et al. Turkey rhinotracheitis virus isolated from broiler chickens with swollen head syndrome in Japan. The Journal of Veterinary Medical Science, v. 57, n. 5, p. 939-941, 1995.

TOQUIN, D. et al. Isolation of a pneumovirus from a Muscovy duck. Veterinary Record, v. 145, n. 23, p. 680, 1999.

TOQUIN, D. et al. Lack of antigenic relationship between French and recent North American non-A/non-B turkey rhinotracheitis viruses. Avian Disease, v. 44, n. 4, p. $977-$ 982,2000

TOQUIN, D. et al. Subgroup C avian metapneumovirus (MPV) and the recently isolated human MPV exhibit a common organization but have extensive sequence divergence in their putative SH and G genes. Journal of General Virology, v. 84, n. 8, p. 2169-2178, 2003.

TORRES, C. A.; HORA, A. S.; BRANDÃO, P. E. Impacto da diversidade molecular das linhagens vacinais de metapneumovírus aviários (aMPV) sobre a proteção conferida pela Nobilis ${ }^{\circledR}$ Rhino Cv. Hora Veterinária, v. 34, n. 199 , p. 28-31, 2014.

TORO, H. et al. Serologic evidence of pneumovirus in Chile. Avian Disease, v. 42, n. 4, p. 815-817, 1998.

VAN DE ZANDE, S. et al. Comparative pathogenesis of a subtype A with a subtype B avian pneumovirus in turkeys. Avian Pathology, v. 28, n. 3, p. 239-244, 1999.

VILARREAL, L. Y. B. et al. Field observations after natural infection of Brazilian layer chickens with a phylogenetic divergent lineage of subtype B aMPV. In: INTERNATIONAL SYMPOSIUM ON AVIAN CORONA 
AND PNEUMOVIRUSES AND COMPLICATING

PATHOGENS, RAUISCHHLOSSHAUSEN, 6., 2009,

Germany. Procedings... Germany, 2009. p. 255-259.

WEI, L. et al. Viral Replication and Lung Lesions in BALB/c Mice Experimentally Inoculated with Avian Metapneumovirus Subgroup C Isolated from Chickens. PLoS ONE, v. 9, n. 3, p. 92-136, 2014.

WEISMAN, Y. et al. Turkey Rhinotracheitis (TRT) in turkey flocks in Israel. Virus isolation and serological response. In: WESTERN POULTRY DISEASE CONFERENCE, 37., 1988, March, Davis. Procedings... March, Davis, 1988. p. 67-69.

WILDING, G. P.; BAXTER-JONES, C.; GRANT, M. Ciliostatic agent found in rhinotracheitis. Veterinary Record, v. 118, n. 26, p. 735, 1986.

WYETH, P. I.; CHETTLE, R. E.; COLLINS, M. S.

Antibodies to TRT in chickens with swollen head syndrome. Veterinary Record, v. 120, n. 12, p. 286-287, 1987.

WYETH, P. J. The rhinotracheitis, swollen head syndrome cause heavy loss. Poultry Digest, v. 49, p. 16-18, 1990.

ZANDE, S. V.; NAUWYNCK, H.; PENSAERT, M. The clinical, pathological and microbiological outcome of Escherichia coli $\mathrm{O} 2: \mathrm{K} 1$ infectious in avian pneumovirus infected turkeys. Veterinary Microbiology, v. 81, n. 4, p. 353-365, 2001.

ZELLEN, G. Swollen head syndrome in broiler chickens: a case report. In: WESTERN POULTRY DISEASE CONFERENCE, 37., 1988, Davis. Procedings... Davis, 1988. p. 139. 